\title{
SECURITY SPHERES: A PHENOMENOLOGY OF MARITIME SPATIAL
}

\section{PRACTICES.}

\section{ABSTRACT}

This article explores maritime protection zones, which are being created in the territorial waters of a number of European states. Through the work of Gaston Bachelard and Peter Sloterdijk, the paper explores maritime zonation as a paradigmatic global security mechanism. It examines how maritime spatial planning seeks to reconfigure sea space into spheres of predictability and rationality. These processes, it proposes, seek to routinize sea space and reconcile tensions between the governance of land and sea, and between fixed infrastructure and mobile capital flows. The paper concludes that space which emerges from a pluralist and less anthropocentric understanding of of the maritime would provide more effective security.

Key Words - Critical security studies, maritime security, globalization, maritime protection zones, Sloterdijk.

Word count: 9,779. 


\section{INTRODUCTION}

This article contributes to our knowledge of spatial security practices. In particular it forms a study of maritime spatial security and the geometry of zoning which undergirds it. As Joyce (2003: 41) has pointed out, the security of space refers primarily to territorializing practices by which knowledge, competency and agency is engineered into the material world. In the maritime sphere it can be examined as an emergent set of processes which seek to classify and reorder the political economy of seaspace, and which assigns it a moral, military, scientific and commercial value.

Maritime spatial planning is an intensification of previous efforts to rationalise the use of global seaspace which, it will be argued, extend into the maritime a logic that has historically informed planning on urbanised space. Nonetheless, contemporary maritime planning projects confront novel problems of scale and distance that do not arise with their urban counterparts. Moreover we hardly need to be reminded of the ocean's materiality as a fluid, constantly changing environment. Understood as a site of uncertainty and chaos, as a heterotopia and as place of adventure (Cohen 2003), the ocean, unlike the land, is generally considered unconquerable (Lehman 2013: 493). 'Unlike human interactions with terrestrial forms of nature', argues Peters (2012: 1243), 'society is less able to shape and mould the sea to its own desires'. Thus, the establishment of maritime protection zones (MPZ) ${ }^{1}$ reveals much about how innovations in scientific data gathering, in spatial planning methodologies

\footnotetext{
${ }^{1}$ The terms maritime protection areas (MPA) and maritime protection zones (MPZ) are interchangeable but the latter term will be mainly used throughout this text.
} 
and in monitoring and surveillance technologies have made it possible to imagine a security network of vast three dimensional zones regulating maritime space.

The three dimensionality of maritime planning relates to the way it layers ocean space so that multiple uses can be assigned simultaneously to the seabed, the sea column and the sea surface. The rationale is that individual economic sectors of the sea are interdependent and rely upon common skills and infrastructure. These sectors include coastal tourism, offshore oil and gas, deep sea fishing, short sea shipping, yachting and marinas, passenger ferry services, cruise tourism, fisheries, inland water transport, coastal protection, offshore wind farms, state monitoring and surveillance activities, military training, blue biotechnology, desalination, aggregates mining, marine aquatic products, marine mineral mining and ocean renewable energies. Three dimensional zoning effectively changes traditional understandings of maritime security which imagined the sea in terms of a unidimensional plane upon which sea lanes were secured for global circulation. Moreover three dimensional zoning has also been instrumental in changing long held geopolitical constructions which tendered sovereignty merely in terms of land-based territory. Territory for littoral states at least, as we shall see, increasingly refers to the de facto sovereignty which covers the seabed, the sea column the sea surface and the airspace above a state's exclusive economic zone.

Steinberg's (2009) historical survey of mapmaking has found that any distinction between terrestrial and maritime environments derives from the social significance historically assigned to ocean space. He points out, for instance, that at the beginning of the sixteenth century, European cartographers did not distinguish between land and sea, insinuating that 'the ocean, like land, was filled with social processes and natural features, and that therefore, like land, it could be bounded, controlled, and organized'. (Steinberg 2009:482). Acknowledging a Grotian outlook more conducive to the growth of seigniorial state capitalism (and colonialism), mapmakers from the seventeenth century constructed sea 
space in terms of routes, as a sphere of navigation, where land and sea were separate entities (Benton 2006). As Brilmayer and Klein (2001:703) have observed, it is for this reason that today 'the international legal regimes for allocation of sovereign rights to land and water areas are fundamentally different.

This article thus marks a shift from scholarship on sea governance or maritime security, which focuses on the novel forms of political structure emerging around the global maritime economy (Bueger and Stockbruegger 2013). Phenomena such as piracy, migration and terrorism form the empirical basis of much of the literature in this field. Following Braudel (1972: 276), who described the Mediterranean in terms of, 'the movements of men, the relationships they imply, and the routes they follow', this literature conceives the sea as a plane of mobility, constituted in terms of risks that threaten its sea lanes (c.f. Struett, Carlson and Nance 2013). The following article supplements this literature by tracing emergent security practices which arise when the sea becomes subject to maritime planning and is no longer simply configured as the sum of its human routes. Normative and technical studies published in the fields of maritime policy, geography and environmental science demonstrate an increasing awareness of the effect maritime zoning is having on the way the sea is experienced (c.f. Joas, Jahn and Kern 2008; Douvere 2008; Monmonier 2010; Suárez Del Vivero et al 2009). Bear and Eden (2008) have critiqued the rigidity of zoning practices that arise from the issuance of fishing licences in the UK. Zoning rationalities have been incorporated in Lobo-Guerrero's (2012) study of strategized space and in Deborah Cowen's (2015) work on the exceptionality and militarization of of port security. Similarly, in an historically informed account, Lauren Benton (2010) has analysed colonial space in terms of zones and routes; as a set of legal corridors and enclaves. The multi-dimensional nature of zonation thus challenges us to revisit Braudel's (1972) route-based imaginary of the ocean. In fact, contemporary maritime security aims to routinize the use of the sea in a manner that 
supports Elden's $(2009 ; 2013: 49)$ argument that dimensions of depth and height are integral to the security of space, and that circulation is therefore not 'contained, controlled and regulated, on a plane'.

The article explores multi-dimensional zoning initially through Gaston Bachelard's 'The Poetics of Space'; a meditation on the relationship between place and metaphysical security. Bachelard's phenomenology places into historical perspective tensions that arise from attempts to secure complex environments of hypermobility. The article traces these tensions and outlines the Apollonian rationality behind efforts to construct routine and continuity by protecting and demarcating a predictable and stable interior from a dangerous outside. By being able to claim a capacity to regulate competing interests and claims on space, maritime governance boasts inclusivity, a scientific rationale and an environmental imperative.

In order to explore these claims the article turns to the recent work by Peter Sloterdijk into the phenomenology of security and spatial spheres. Although influenced by him, Sloterdijk has pushed Bachelard's provincial Dionysian materialism to conceptualise security practices operating in the fluid, dynamic, and rootless globalized spaces of the twenty-first century. Sloterdijk (2013a: 89) has critiqued a blindness towards the sea evident in the writings of Kant and other continental philosophers (including Heidegger) for remaining tied to the perspectives of deep-rooted, terran-regional self assertion'. Intensely curious about the 'maritime action space', Sloterdijk's work presents modernity as a space of artificial security constructions that are metaphorical spheres; three-dimensional, self-immunizing enclosures afloat in volatile and unpredictable materiality. Multi-functional zoning at sea conforms closely to the topology of spheres critiqued by Sloterdijk, who describes globalization shaping space through new procedures that create 'synchronous world routines' (Sloterdijk 2012: 172). The paper is thus able to propose that zoning and routinization is an exemplar globalization strategy that seeks to gentrify rural and wilderness sea spaces (Hellström 2007: 
423). From a security perspective, it demonstrates the freedom of the sea gradually being refashioned to reflect the hierarchy of values and differentiated rights of access that defines our urban landscapes and critical infrastructures (Graham 2010).

\section{ZONAL SECURITY AND THE SEA}

Throughout the twentieth century, the classical freedom of the high seas, so pivotal to liberal political economy and to the security of seigniorial maritime powers for three hundred years was subject to a process of strategic modulation. Shipping lane security, which historically structured our understanding of sea as 'as an empty void to be annihilated by hypermobile capital', is currently being disrupted and supplemented by a construction that frames the sea not as a void but as a 'resource-rich but fragile space requiring rational management for sustainable development' (Steinberg 1999c: 403). The well-being of the sea and the destiny of globalization have been intertwined in this narrative. With the emergence of zoning, the two-dimensional lines demarcating the swiftest and safest routes no longer move things and people through empty blue space: they now pass through three-dimensional, multifunctional security zones. By cordoning off space for discrete functions, zones add value to specific sites, and therefore increasingly carry a territorial and managerial rationality to the formerly apolitical, route-based logic of ocean movement (Ryan 2013).

It is possible to trace zoning back to early modernity when ocean space was first named and a thus appropriated by colonial maritime powers. Carl Schmitt (2006) has traced global twodimensional linear zoning to amity lines drawn in the late fifteenth century by Pope Alexander VI. Zoning practices have however accelerated in the twentieth century and are 
most immediately detectable in the complex spatial system of fishery management, ecological, hydrographic and statistical-oceanographic categories that are rudimentarily managing world sea space. In addition to subdivisions of oceans and seas carried out by the International Hydrographic Office since 1928, vast macro-zones have been carved out by the United Nations Environmental Programme (UNEP), which has identified sixty-four large marine ecosytems in world ocean space. Within and around the 200,000km of UNEP protectorates are eighty-eight major fishery zones delineated by the Food and Agricultural Organisation (FAO). Supplementing this complex matrix are forty-six UNESCO marine heritage sites (Douvere 2008). As Suárez-de- Vivero et al (2009:628) have pointed out; one can locate thirteen European partitions alone dividing up the waters of the North East Atlantic, the Mediterranean Sea and the Black Sea. Sub-divisible into more or less governable, or commodifiable units, amongst these macro abstract demarcations of sea space lie exclusive economic zones (EEZ) and fishery zones, which attained a jurisdictional status through customary and international law over the past century.

It should be noted that even under the liberal Grotian regime that persisted for 300 years, states possessed sovereign rights over their internal waters and their territorial seas and beyond that limited jurisdiction over a contiguous zone for security purposes. ${ }^{2}$ Following a claim in the early $19^{\text {th }}$ century by France, Belgium, Spain, Portugal, Norway, Sweden, Russia and the United States claimed jurisdiction within $20 \mathrm{kms}$ of their territorial sea to enable the enforcement of 'customs, fiscal, immigration and sanitary regulations' (Colombos 1967: 145146). Nonetheless, the origins of land-based governance segueing into a system of high sea governance might be traced back to the 'patrimonial' claims initiated by Colombia in 1919, when it claimed an exclusive right to exploit hydrocarbons beneath the territorial sea. While

\footnotetext{
2 There are seven categories of maritime space through which sovereign rights and duties adhere. Internal waters, archipelagic waters, territorial seas, contiguous zones, continental shelves, EEZs and fishery zones.
} 
this move was followed by Panama, Venezuela and Argentina - all of who sought to protect fisheries and mineral reserves - it was not until the end of World War Two that we can properly point to the first moves to territorialize the high seas. In the Truman Declaration, September 1945, the US laid claim to jurisdictional authority over its continental shelf and fisheries resources. Historically this marks a departure from Britain's dominance over ocean space and the birth of the US as a global naval power. While carefully preserving the strategically vital principle of freedom on the high seas, the US declaration demonstrated the economic possibility afforded by technological advances of claims over sea space (Krueger and Nordquist 1978). As Nye (1975:33) has observed, states that were less developed, and less likely to profit from what China called the 'hegemony and expansionism' inherent in high seas freedom, reacted to the US declaration with their own protectionist sovereign claims. Between 1974 and 1982, in the face of resistance from the United States, Latin American and African states were pushing the norm of 12 nautical miles (territorial sea) towards a 200 nautical mile EEZ at the negotiations around UNCLOS III. Article 55 of Convention that emerged from these negotiations in 1976 codified the EEZ at this distance, granting states sovereign rights for the 'exploration, exploitation, conservation and management of all natural resources and other economic activities' (Krueger and Nordquist 1978: 329). Enshrining mobile rights within an emerging zoning regime, associated rights and duties of states included the right of navigation and overflight, and the right to lay submarine cables and pipelines. ${ }^{3}$ Thus, while the jurisdictions of states such as France, the United States and Australia were significantly increased by the Law of the Sea Convention, the legislation simultaneously guaranteed seigniorial maritime powers unimpeded rights of mobility around a three-dimensional global sea space. The Convention therefore sought to

\footnotetext{
${ }^{3}$ Thirty four countries enjoy sovereign rights beyond the 200 nautical mile limit; where the continental shelf extends beyond a coastal state's EEZ, it is entitled to jurisdiction over the seabed and subsoil up to 350 nautical miles.
} 
secure a sort of juxtaposition; facilitating the cohabitation of fixed, long term infrastructures with free flowing capital.

By 2013 it was estimated that $58.4 \%$ of the world seas and oceans had come under national control (Súarez-de-Vivero 2013: 117). Undoubtedly, EEZs have given rise to new practices of national security, evidential in the rising number of national maritime security strategies being published. However, of concern to this study is the dramatic reconfiguration of sea space occurring within these 'nationalised' exclusive zones.

Zoning is profitably understood as a taxonomical process: as technological capability increases and scientific knowledge of the ocean expands, the global maritime is being systematically sub-divided into ever smaller administrative units (Ryan 2013: 177). While these developments were still at a rudimentary stage, Schmitt (2006) had identified the impulse to draw lines and divide ocean space as the 'new nomos of the earth'. What is increasingly evident is that this new nomos refers to the territorialisation of sea space; a new arrangement or redistribution of political and economic power that creates new meaning in social space (Brown and Lunt 2002). Thus, the phenomenon at issue concerns a territorialization of sea space that, it will be shown, emerges through a security architecture that operates in cities, in rural areas and in airspace (Williams 2011). Understanding maritime spatial planning as the strategic parceling up of open space enables us to locate a constant tension on the sea between what Deleuze and Guattari (2008) termed smooth and striated space. Striated space, as Osborne and Rose (2004:218) point out, is fixed space that 'bounds structures, frames and locates action; and practices of discipline, regulation, subjection take place inside these spaces'. Striated space interacts with smooth space, which is ungoverned, nomadic, barbaric and continually challenged by the state's will to striate (Hillier 2007:64). Materialist ontologies of security enables us to better comprehend how 
zones mediate between between a rooted, terrestrially-derived (striated) mode of governance and a (nomadic) smooth space perspective more conducive to capital flows.

Prior to exploring the empirical development of maritime spatial planning, the next section will present a phenomenological account of socio-spatial security practices. It will outline the rationality of routinization at work within efforts to construct blue economies. The paper will argue that while maritime zoning is dissolving traditional distinctions, such as that between land and sea, it is simultaneously drawing new exclusionary lines. Prior to making this argument it is imperative we understand the ontology of security at work in the techniques used to govern complex fluid spaces.

\section{Securing Late Modern Space}

In the late 1950's Gaston Bachelard's 'The Poetics of Space' produced a phenomenological account of how local space generates metaphysical security. For Bachelard (1994) security emanated from the vital materiality of an object. His abiding image of a home is a rural place where memories and dreams are rooted and consciousness is centralized. Bachelard introduces the idea of verticality to his conception of security by associating the garret with memory and roots, the ground floor with everyday reality and the attic with imaginative becoming. Home is where well-being is housed and security is imagined as an organic refuge that is at once relational with its environment and yet protective. Bachelard (1994:27) contrasts this metaphysically porous home with 'mechanical' modern urban habitation; 'where houses are no longer aware of the storms of the outside universe', and where 'the relationship between house and space becomes an artificial one'. Life in Paris incites Bachelard to ask how one can feel secure in an urban space. In response he invokes a comparison between the noise of the city and the roar of the ocean: 'we all know that the big 
city is a clamorous sea' he writes, imagining the noise of traffic to be waves and wind and his bed as a skiff (1994: 28). As we shall see, this analogy between the city and the dynamism of the sea endures in current processes of maritime security.

Bachelard's mid-twentieth century attachment to the local finds resonance in an anthropological study undertaken by Tuan (1977). Tuan observed that for the ancient cultures in the Middle East and the Mediterranean Basin secured space had a mystical foundation. In early Mesopotamian towns, writes Tuan, ‘when life seemed uncertain and nature hostile, the divinities not only promoted life and protected it, they were also the guarantors of order in nature and society' (1977:150). Yet one has to only look at ancient Greece to appreciate the extent to which this strategy of good order came into tension with the disorderly nature of the sea upon which Athenian thalassocracy depended. This tension is a major political theme in the works of Plato and Aristotle. In these writings the sea becomes symbolic of the destablizing democratic demands of those living and working in the port of Piraeus (Hale 2014). The sea was therefore constructed as somewhere diseased, lustful, drunken and lost (Rancière 2007). It embodied the chaotic, intoxicating and fatal divinity of Dionysus. Dionysus was a sailor, a foreigner that had come from the sea and the antithesis to Apollo, the divinity of Platonic form, symmetry and good spatial order (Akkerman 2006: 237).

While the link between localism and divinity was transformed in the wake of the Copernican secular revolution, the essential values of order - rationality and moderation remained (Fletcher 2009). Apollonian values expressing security as a function of calmness and predictability remained extant as their ancient roots became unmoored by a new and liberal formation of spatial security that wrestled with generating circulation in an age of openness, flows and movement (Joyce 2003). Indeed, the early-twentieth century urban planner Hans Blumenfeld (1949) observed that the principle of axiality has entirely 
dominated urban planning since the Renaissance by foregrounding routes as the producers of space through cities. By emphasising the city's grandeur, he notes, streets have served to express the political unity and majesty of the state (Blumenfeld 1949:26). Routes, in other words, established the new 'ground' upon which political and economic power was redistributed (Virilio 1986:12). The foundation of this nomos is no longer solid, firm ground upon which we stand; it is an ever-shifting and fluid surface upon which we float (Anderson 2012).The ontological utility provided by roots had somehow to be transplanted onto the new and highly insecure nomos of movement and flow to govern a society open to the forces of capital. The ontological 'problem' of reconciling these apparently antithetical properties has been one that undergirds the modern security dilemma.

The study of maintaining ontological security in an insecure modern environment received a lot of attention from Anthony Giddens during the 1990's. Giddens' work was influenced by R.D. Laing's understanding that security was a psychological phenomenon rooted in one's self being unified, useful and rational (Laing 1990:39). Affirming a border between ontologies of internal and external security, and drawing again upon Laing (1990a), Giddens (1991), posited home as the private zone which nurtures and protects a sense of being secure in the face of a public sphere where security is based on constant surveillance. For Giddens, ontological security is the state of possessing 'answers to fundamental existential questions' ... and 'reproducing these answers in the form of actions that take on the appearance or shape of a routine' (Steele 2005:526). His motivation is to create a form of security based on continuity over space and time in trusting, predictable relations between actors that will protect the individual from 'existential anxiety'. In other words, Giddens is linking ontological security with calmness and with a unity of meaning and home; and insecurity with external uncertainty and fragmentation (Dupuis and Thoms 1998). When his foundational ontology is raised up to the level of state security we can see more clearly the 
Apollonian legacy. In the work of Jennifer Mitzen (2006), Giddens' ontological security is reworked for state security. Unsurprisingly, she emphasises the predictability of routines. She notes that routines produce certainty, enables 'purposive choice' and inoculates individuals from the 'paralytic, deep fear of chaos':

routines are not chosen in any meaningful sense, but taken-for-granted; reflection is suppressed. In fact this suppression is the source of their securitygenerating power

(Mitzen 2006; 346-347)

Such routinization, it has been observed, has been used to distract from our primordial fear of the sea. A paper by Antonnucci (2006) recounts how with the launch in 1843 of metal constructed vessels, ships became a larger, ever more luxurious form of transport better able to tranquillize its passengers. The introduction of brightness to the dark recesses of old galleys enabled ships to provide comfort for passengers. The relation between the sea and the passenger became secured in the routinzation of sea-crossings amidst bourgeois interiors that were designed to remind one of home and replicate the most spectacular architectures of the state apparatus. Again we are reminded of Apollo, this time as the god of light. Here we see his brightness produce the calm that is required to dispel the fear of the externalized sea. The passenger at sea is secured by replicating the attributes of a well policed city - the hold is made to feel as firm as a city, immunized against the elemental flux outside. As Easterling (2005:23) has so eloquently demonstrated, contemporary ocean liner cruising' replicates an 'enclosure of familiarity'. ${ }^{4}$

Easterling's purposeful use of the word 'enclosure' relates to how she treats cruise liners as cages of comprehension, or umwelt, for Heidegger (Sutrop 2001). Literally the 'world-

\footnotetext{
${ }^{4}$ Emphasis added.
} 
around-us', umwelt describes technical or political enclosures that mark a limit between what we understand and the world around us (Ten Bos 2008). As do the wealthy cruise liner passengers in Easterling's analysis, the inhabitants of these enclosures can travel anywhere and remain oblivious to the fact that their security is housed by vulnerable social constructions of reality. ${ }^{5}$ Peter Sloterdijk's (2011) work has done much to conceptualise these enclosures and the ontological security they aim to replicate in his major work on spheres. In fact, Sloterdijk's philosophy provides us with remarkable insight into the rationale behind zoning.

\section{Sloterdijk's Spheres}

From this conceptualization of umwelt, the metaphor of the circle has emerged as a means to articulate the ontological geometry of our surrounding (in)security. As Bachelard notes; 'thus, in being, everything is circuitous, roundabout, recurrent' (1994:214). Or later, 'das Dasein ist rund. Being is round' (1994: 239). Much of Peter Sloterdijk's work can be read as a response and an elaboration of Bachelard's phenomenology of security and space. As with Bachelard, Sloterdijk's metaphysical being takes the form of roundness in his major work on spheres (2011). The sphere is therefore a human made ontological construction for Sloterdijk and a form from which he interrogates the possibility of security in a decentralized, fluid and contested global environment. Sloterdijk argues from a Heideggerean position that modern security practices reproduce 'prosthetic husks' (2011: 24), human spheres which are ultimately as vulnerable to material forces as soap bubbles blown by a child into the air. Sloterdijk's philosophy of space is thus inherently liquid and it tells us something about the

\footnotetext{
${ }^{5}$ As Dillon $(1996 ; 125)$ reminds us, the etymology of the Latin securitas can be traced to the phrase sine cura, to be free from care. It was also used to describe a thing that possesses a false sense of certitude, a groundless sense of security.
} 
morphology of maritime planning. As three-dimensional, multi-functional, enclosures of space, the architecture of maritime zones resonates with the qualities of Sloterdijk's 'bubbles'.

For Sloterdijk, by generating freedom at the expense of metaphysical security, our epoch is defined by its will to uproot traditional experiential and cultural forms of local security. Substituting place-specific gods, myths and culture for science, universalised rationality and individualism, globalization decrees that 'enormous populations, at the center as well as at the margins, must be evacuated from the old cosy temperate regional illusion and exposed to the frosts of freedom' (2011: 27). The consequent sense of exposure compels us to huddle in what Klauser (2010: 329) describes as, 'self-animated spaces of togetherness'. The symbolic spheres Sloterdijk finds throughout modernity's cultural history serve as artificial replicas to ancient roots. They are globular in shape, moulded in the image of the very obsolete cosmological and theological narratives that once shielded ancient civilizations within 'celestial domes' (Sloterdijk 2011: 25; 2009). Thus modernity is defined by its desire to respond to the very question that Bachelard posed from his apartment in Paris; how to reconstruct metaphysical security in the face of a rootless and dynamic formation of political and economic freedom that rips well-being from its ontological source?

An ensemble of heterogeneous bubbles coagulating to form an ungovernable 'foam', his philosophy of space describes routinized enclosures floating together in the midst of a hostile externality. Klauser $(2010 ; 332)$ cites Sloterdijk's observation that, 'for this organism the biggest part of the environment is either toxic or meaningless'. It is beyond the limits of its understanding. The tendency of the exposed human is to seek a safe zone: 
Humans are self-fencing, self-shepherding creatures. Wherever they live, they create parks around themselves. In city parks, national parks, provincial or state parks, eco-parks - everywhere people must create from themselves rules according to which their comportment is to be governed

(Sloterdijk 2009:25)

Inhabiting these security bubbles are humans who have lost touch with what really surrounds them, the material world (Sloterdijk 2013). Attempts to purify space, their spheres are sterilized zones of socially constructed security. Referring to them in terms of being immunized (atmo)spheres, his ensembles of security are occupied by the selfquarantined. Zygmunt Bauman, has drawn similar conclusions in work that examines the insides of security communities, describing a a 'self-enclosed place without a place' where 'the differences inside, unlike the differences outside, are tamed, sanitized' (Bauman 2000; 99). A global way of life can be safely conserved in the hotels, shopping malls, airports, and cruise ships which exhibit themselves as purified placeless spaces.

What distinguishes Sloterdijk's topolphilia from previous ontologies such as Bachelard's, according to Ten Bos, is that it is situated in the flux of ocean, rather than the firmness of land. 'Being is understood as "being surrounded" and "being flowed through" especially as being together in a watery element'. (Ten Bos 2008:78). Sloterdijk is fascinated by the human impulse to construct islands. Here it is worth citing Ten Bos at length:

Nowadays, we use different technologies: we construct absolute islands aiming at a complete isolation from the surrounding environment (aircraft, spacecraft, and so on); we construct atmospheric islands that aim to control temperature and climate (greenhouses, air-conditioned offices, and so on); we also construct 'anthropogenic' islands which are supposed to carry people and keep them together. Sloterdijk devotes hundreds of pages to such islands that allow us to become the human beings we are: organisations, companies, sports clubs, sects, families, neighbourhoods, countries, empires, states, temples 
(Ten Bos 2008: 81)

Maritime protection zones ought to be understood as areas abruptly cordoned off from the Dionysian frenzy of the sea. They are enclosures of Apollonian rationality that aim to anchor a sense of control and predictability to a volatile environment. By routinizing activity within the enclave, maritime planning embodies the exclusivity of free trade zones and other economic zones that structure the politics of mobility on land (Cresswell 2010), which is constituted by 'more or less purified insides and more or less dangerous outsides' (Klauser 2010:332). As we shall see, it is this exclusionary impulse that undergirds contemporary attempts to striate the maritime zone

\section{THE MARITIME PROTECTION ZONE (MPZ)}

Sloterdijk's phenomenology of the sphere enables us to discern core aspects of late modern security practices that are embodied in maritime spatial planning. Certainly there is a spherical ontology at work in these new sub-categories of marine space. The jurisdictional limits wherein planning occurs are designated from a baseline by 'drawing overlapping circles centered along the low water shoreline' (Monmonier 2010:71). The geographer Mark Monmonier (2008: 104) explains; 'In theory a maritime territory or [exclusive economic] zone is defined by a multitude of overlapping circles, twelve to two hundred miles in radius, centered at every point along the shoreline'.

Within these exclusive economic zones, maritime spatial planning identifies spheres where, for commercial, environmental or military purposes, human activity will be regulated. Thus 
it is not the materiality of the sea that is being secured, but the relationships between various actors who use the sea. In Sloterdijk's terminology, zoning reconfigures the sea by uprooting traditional relationships between the sea and its users and initiates new procedures and routines. By striating sea space, maritime planning embeds a hierarchy of values which illustrates that zoning is a form of protection that serves particular ways of life, while affecting the potentiality of other forms of life to survive.

Indicatively, the goals of maritime planning are to 'describe, visualize and realize rights, restrictions and responsibilities in the marine environment' (Strain, Rajabifard and Williamson 2006 :434). Emerging as a legal possibility from UNCLOS III, a number of global frameworks have been generated around these goals. Agenda 21 for instance, in 1992, established the norm of sustainable development of marine environments and its resources. The Convention on Biological Diversity, held in 2004, included frameworks for ecosystem place-based management using 'an integrated network of marine and coastal protected areas'. The World Summit on Sustainable Development, in 2002, promoted the use of land use planning tools for marine spatial planning (Douvere 2009). The originary marine protected zone is considered to be the regime placed around Australia's Great Barrier Reef Marine Park, finalized in 1994. Since then legislation has passed in Canada in 1997 (Oceans Act) which created a national oceans strategy to manage the country's estuarine, coastal and marine ecosystems. The United States has been active in this regard with 25 zones having been specified on the Florida Keys National marine Sanctuary Management Plan (Douvere 2008:767), while China passed its Law on the Management of Sea Uses on 27th October 2001 which divides its EEZ into different types of functional zones.

The European Union launched its spatial maritime policy in 2007 based on its understanding that seaspace planning could regulate the competition for space in European waters (Meiner 
2010; Schäfer and Barale 2011). ${ }^{6}$ The policy is driven by an economic agenda that describes spatial planning as a management tool which will increase investment certainty, coordinate the implementation of offshore energy, frame national decisions within an ecosystem (transborder) manner and ensure consistency between land and marine systems. Europe's 'Blue Economy' is premised on the claim that marine knowledge, maritime spatial planning and maritime surveillance are integrated means which will 'reduce administrative and operational costs for businesses and increase certainty on appropriate access to maritime space, thus favouring private investment' and increase the effectiveness and cost-efficiency of about 400 public authorities'( EC 2013:1). Marine energies (offshore wind power and emerging techniques), aquaculture, tourism, biotechnology and marine mineral resources have been identified by the EU Commission as its five strategic economic priorities. 7 The emphasis is on extending Spatial Data Infrastructures developed on the terrestrial environment into the maritime arena. In July 2014, the CISE - Common Information Sharing Environment - was launched in the EU to bring 'together surveillance data from civil and military authorities like coast guards, navies, traffic monitoring, environmental and pollution monitoring, fisheries and border control'.$^{8}$

Related to the political problem of data sharing is the related problem of reconciling the land based administrative logic of planning with the more dynamic and fluid approach required to manage the smoothness of the sea. This is being tackled by not only introducing landbased municipal or regional zoning to the sea, but by integrating sea space into comprehensive land planning. Hence the sea is divided into specific use areas that mirrors

\footnotetext{
${ }^{6}$ http://eur-lex.europa.eu/LexUriServ/LexUriServ.do?uri=COM:2008:0791:FIN:EN:PDF accessed $24^{\text {th }}$ April 2013.

${ }^{7}$ http://ec.europa.eu/maritimeaffairs/policy/blue_growth/documents/com_2012_494_en.pdf accessed 24th April 2013.

${ }^{8}$ EU Press Release Maritime surveillance: Joining forces with Member States for safer seas and oceans European Commission - IP/14/782 08/07/2014. Accessed 21/07/14 on http://europa.eu/rapid/press-release_IP-14-782_en.htm
} 
and extends zoning practices on land - 'ship channels, disposal areas, military security zones, concession zones for mineral extraction, aquaculture sites and most recently marine protected zones' (Douvere 2008: 762; Sanchiro, Eagle et al 2010). By regulating human activity in the sea, UNESCO literature envisages the management approach usurping the more traditional politics of the sea (Ehler and Douvere 2007) by;

Analyzing and allocating parts of the three-dimensional marine spaces to specific uses, to achieve ecological, economic and social objectives that are usually specified through the political process.

The Netherlands, France, Norway, Germany, Spain, Portugal, the UK and Poland, amongst others have initiated maritime zoning projects around Europe (Suárez de Vivero and Mateos 2012; Douvere and Ehler 2009). Germany extended its terrestrial spatial planning legislation to cover it's EEZ in 2004, stretching existing land planning to its coastal area and into the sea. Britain, due to its historical role as the harbinger of free high seas had been slow to proclaim an EEZ and did so in March 2014 it seems, to facilitate maritime spatial planning. ${ }^{9}$ The British policy concretely binds marine and land planning so that the 'marine area will overlap with that of terrestrial plans ... and will not be restricted by an artificial boundary at the coast' (HM Government 2011: 9). There is a more ardent environmental aura in UK plans but, as with European level blueprints, socio-economic and national defence priorities are given priority over ecological arguments (Wakefield 2010). A national agency, the Maritime Management Organisation (MMO) was instituted to 'co-ordinate an enforcement programme for monitoring, control and surveillance of all sea fishing activity'. ${ }^{10}$ Intimately tied up with a newly produced National Maritime Security Strategy, published in May 2014,

\footnotetext{
${ }^{9}$ It should be noted that the UK in the British Indian Ocean Territory declared an MPZ in 2010 around the Chagos Archipelago. It is twice the size of the UK and is currently the world's largest nature reserve. Critics have pointed out that the unilateral establishment of this 'non-fishing zone' effectively prevents the return of its indigenous population, deported in 1968-1973 to facilitate the construction of the strategic US naval and airbase in Diego Garcia (Sand 2012).

${ }^{10}$ http:// www.marinemanagement.org.uk/fisheries/monitoring/index.htm
} 
eleven offshore and inshore marine plan areas have been identified by British authorities. Aiming to have completed maritime planning by 2034:

The approach enables sustainable commercial fishing, shipping, aquaculture, aggregate extraction and other activities to grow, while allowing the development of new business opportunities, ensuring safety at sea and protecting the environment. Essential infrastructure for the onward transportation of goods or energy is in place along the coast

(HM Government 2014: 4)

Neo-liberal commentators, who refer back to the rationality of the negotiations and the environmental benefits accruing from EEZs, argue that MPZs are based on the economics of efficient resource allocation and consensus (Young 1982, 2009; Hallwood 2008). This line of arguments flows around debates concerning the benefits of enclosure versus commons and eventually provides evidence for commentators seeking to privatize maritime space (Hannesson 2006: Osherenko 2006). Thus, primarily an MPZ is presented as a technical solution to the problem of reconciling new fixed infrastructures with older and mobile 'activities' on the sea (Oxman 2006). Maes (2008:797), for instance, observes a growing tendency for fixed investments such as 'wind and wave energy, cables and pipelines, coastal defence, port infrastructure, aquaculture and land extension' to be vying for space in the sea with older mobile activities such as 'fisheries, shipping, air transport, military use, water recreation' etc. As Smith, Maes et al (2011) insinuate, static interests are generally more concerned with the use of the seabed, while mobile uses, including pelagic fish and shipping routes, utilize the water column and sea surface. Maritime spatial planning layers ocean space so that multiple functions can be assigned simultaneously to the seabed, the column and the surface area. 
Belgium's is one of the most complete zoning projects and its effect on the use of the North Sea is regularly cited by maritime policy experts. Belgium presents an interesting case to exemplify the approach to interpreting sea space. As Douvere et al (2007:189) observe, 'A crucial step in the creation of an overall structural map for future MSP in Belgium was to generate different strategic visions'. Based upon the three core values - well-being, ecology and landscape, and economic value - scenarios were imagined until a vision of the Belgium EEZ emerged as:

i. the relaxed sea, focusing on well-being

ii. the natural sea, focusing on ecology and landscape;

iii. the rich sea, focusing on economy;

iv. the playful sea, focusing on both well-being, and ecology and landscape

v. the mobile sea, focusing on both ecology and landscape, and economy, and

vi. the sailing sea, focusing on both economy and well-being. ${ }^{11}$

(Douvere et al 2007;189)

Belgium's maritime spatial plan was presented as a management device to regulate a space that was seen to be too anarchic, with too many conflicting users of too few resources. Having gathered geological, biological and ecological data, homogeneous zones were located and demarcated. Legal, technical and socio-economic surveys were subsequently done on each provisional zone to measure the effect of it being delineated for a certain use.

In contrast to the Belgian schematic, when the Dutch instituted processes for the stratification of its sovereign waters, weightings were assigned to zonal valuations. This meant that a hierarchy was established amongst the various visions of the sea offered. Leading commentators were supportive of this approach, arguing that the hierarchy of values needed to be standardized, globalized even: 'National plans', argues one leading expert, 'should be translated into international policy in which sea uses should be planned

\footnotetext{
${ }^{11}$ Though not included in the above constructions, the military sea is incorporated into the zones which were drawn up around these six constructions.
} 
to complement one another on an international scale' (Douvere 2007:191; Ardon,et al 2008). Commentators have lamented the 'paucity of MPAs in the High Seas' (Agardy, di Scarra and Christie 2011; Kirk 1999). They point out that the technology surrounding Vessel Monitoring Systems 'allow surveillance today at levels not possible a decade ago' (Agardy, di Scarra and Christie 2011;231). The affordability and coverage of this technology, it is argued, opens the possibility for global maritime spatial planning by linking protected zones in the EEZ's to areas in the high seas. This proposition chimes with studies that point out a need for transnational governance of the maritime environment (Joas, Jahn and Kern 2008). When Smith Maes et al (2011) visualize the global maritime in terms of its proximity to terrestrial governance structures, they point out that zoned waters are effectively urbanized seas. This urbanizing impulse is very evident in the functional visions attributed to the sea in the British, Belgian and Dutch plans. Actual cities and towns are zoned by similar visions of order. As Osborne and Rose (1999) pointed out, the late modern city of advanced liberalism is a healthy city - a city of well-being. It is imagined as a risky city - a city monitored and continually assessed; it is a city of enterprise - 'a node within pathways of mobility, a matrix of flows ... which connect persons, processes and things; (Osborne and Rose 1999:757). The globalizing impulse implies extending these urban sea blueprints outwards into what Maes, Smith et al (2011) term the rural and wilderness seas.

Steinburg (1999) has argued that the prevailing ocean imagery that drives the values of maritime spatial planning needs to be overcome. What he terms the 'maritime mystique' evident in the Belgian case occludes the voices of those who those who earn their living from the sea. 'Seafarers, dockworkers and artisanal fishing communities' among others are being 'managed out of existence by the regulatory strategies with which each image is aligned'. Notwithstanding a commitment to participation and stakeholder inclusion, which features in the policy literature, a study conducted by St. Martin and Hall-Aber (2008) has observed 
how geo-technologies are eclipsing the 'human dimension' to reforming the use of sea. GIS (Global Information Systems) is the primary MSP technology, used to provide the foundational data and produce the analyses and visualization of the space to be regulated. 'Neither the complexity of human communities nor their relationship to locations and resources at-sea are represented in the current data collection initiatives', they observe (St. Martin and Hall-Aber 2008:779).

There is some evidence therefore to suggest that the same relatively rigid top-down classifications of urban space based on morality, hygiene and order which marked planning in the $20^{\text {th }}$ century is extant in maritime planning. Recalling 'the postwar rush to turn planning into an applied science' it has been observed that much was ignored - 'the city of memory, of desire, of spirit; the importance of place and the art of place-making; the local knowledges written into the stones and memories of communities' (Sandercock 2003;2 cited by Tewdwr-Jones and Morphet 2010;243).

Sloterdijk's spheres help us to conceptualize this tension emanating from the exclusivity of zones: one emanating from communities whose relationship to the sea, and whose ontological security, has been uprooted by the sudden presence of maritime spatial planning. Dionysian materialists, as we see, point out that security emanates from one's rooted relationship to place. Regarding the scientific-technical discourse around which maritime security is developing, one seasoned commentator has observed that 'scientific distancing and objectification has to be complimented with tacit knowledge about sociocultural settings' (Haila 2008). Particularly with maritime political economy this would imply that zoning needs to be a 'more open, multiple and relational activity that can adjust to the fluidity of politics' (Twedwr-Jones and Morphet 2010: 243). The nature of Sloterdijk's spheres incites us to ask if commercial, environmental, scientific and military interests at sea 
are constructing bubbles of routine that secure against local voices, treating them as the dangerous external force of chaos and unpredictability.

\section{CONCLUSION}

A common theme pervades studies of maritime planning emanating from the social sciences. These studies find in zoning an architecture of governance that is ill-tuned to the materiality it seeks to secure, one unlikely to fulfil its ecological function. Designed for the production and harvest of marine life, rather than its conservation, studies point out that maritime spatial planning serves a commercial, rather than an environmental, purpose (Bear and Eden 2008). Moreover commentators have voiced suspicion about planning processes that exclude local coastal and fishing communities. Maritime spatial planning tends to standardise, or routinize, sea space. The dichotomy of Apollonian land and Dionysian sea is erased; certain procedures are installed that are common to both domains and a surveillance and monitoring regime is constructed. By being able to scientifically analyse, plan and predict the usage of space it acquires an economic worth. A hierarchy of value is constructed - some spaces are deemed to be more productive than other spaces and a market comes into being. Thus we are witnessing maritime borders, traffic corridors and multi-floored administrative enclaves reproducing a very modern formation. This structure is designed to manage vast three-dimensional, inhospitable environments through a network of secure routes connecting orderly, gentrified sites. The socio-technical imaginary at stake is a global network of secured zones that act as rational hubs of wealth creation and environmental management in the maritime sphere. Yet there is a distinct martial undertone in the blueprints of maritime spatial planning. It is increasingly tied to the production of national (and regional) maritime security strategies, for instance. Moreover, other accounts of zoning, 
such as Cowen's (2015) study of container port security, which is inextricably tied to maritime planning, demonstrate continuity with the commercial-military nexus that has historically animated the maritime sphere. Human and non-human life, as it flows through these multi-dimensional spheres, is not so much lived, as it is zoned, monitored and routinized.

The phenomenologist's preoccupation with space assists critical scholars of global politics in any bid to articulate alternatives forms of security. The reconfiguration of the sea - the political and economic redistribution being undertaken and the synchronous and incipient territorialisation - is producing new knowledge and policing technologies of governance that will inevitably be transferred between other 'ungoverned' open spaces. Wilderness areas such as deserts and mountains, intelligence blackspots and so-called failed states are ubiquitously described as sources of unpredictability, crime and ontological insecurity.

Sloterdijk's work on spheres provides us with insight into the rationality behind the security of complex space.. His genealogy traces the political theology of spatial security practices and connects it with the ambitions of globalization. We can find in his work an account of modernity's will-to-zone, to equate security with social constructions of certainty and predictability. These zones are 'bubbles' of routine for Sloterdijk, miniature spheres of existence in which one feels immunized from the externalised world around. The article contrasted this Apollonian conceptualisation of security with Sloterdijk's understanding of a secure space. Echoing and elaborating on the Dionysian materialism and localism of Gustav Bachelard, he seeks security in the sense of a home that is rooted in its surrounding environment. Rather than imposing a standardised design on fluid space, Sloterdijk calls for more open, relational spaces that allow their human and non-human inhabitants to thrive. The question thus arises how maritime spatial security doctrine can incorporate an inherently more inclusive and less anthropocentric imaginary of seaspace. This would seem 
to imply spatial planning that seeks to radically localise maritime space rather than globalise it. Space, it is argued, is not a mechanistic object that can effectively be globally reproduced and distributed. Ultimately, it suggests adopting a view of space that is not constituted by biopolitical borders, hierarchies of access, exceptionality and market logic. The challenge therefore set by Bachelard and Sloterdijk is for maritime security to emerge around an organic, dynamic set of relationships constituted by human and nonhuman ways of life, memory, emotions and experience.

\section{BIBLIOGRAPHY}

Agardy, T; G. Notarbartolo di Sciara; P. Christie, (2011), Mind the Gap: Addressing the Shortcomings of Martine Protected Areas through Large Scale Marine Spatial Planning, in Marine Policy, Vol. 35, pp.262-232.

Akkerman, A., (2006); Femininity and Masculinity in City-Form: Philosophical Urbanism as a History of Consciousness, in Human Studies, Vol. 29, pp. 229-256.

Anderson, J., (2012), Relational Places: the surfed wave as assemblage and convergence, in Environment and Planning D: Society and Space, vol.30, pp. 570-587.

Antonucci, R., (2009), In the Clouds of Joseph Farcus: The Phenomenology of Going to Sea in the Era of Supermodernity, in Design Issues, vol 25 (4), pp.36-50.

Ardon, J.; K. Gjerde, S. Pullen; V. Tilot, (2008), Marine Spatial Planning in the High Seas, in Marine Policy, Vol.32, pp. 832-839.

Bachelard, G., (1994), The Poetics of Space. Beacon Press: Boston. 
Bauman, Z., (2000), Liquid Modernity. Cambridge. Polity.

Bear, C. and S. Eden (2008), Making Space for Fish: the regional, network and fluid spaces of fisheries certification, in Social and Cultural Geography vol. 9(5), pp. 487-504.

Benton, L., (2010), A Search for Sovereignty; Law and Geography in European Empires 1400-1900.

Cambridge: Cambridge University Press. Benton, Lauren, (2006), Spatial Histories of Empire, in Itinerario, vol.30 (3), pp.19-34.

Bueger, C.; J. Stockbruegger, (2013), Security Communities, Alliances, and Macrosecuritization: The Practices of Counter-Piracy Governance, in Struett, Carlson and Nance (eds), (2013), Maritime Piracy and the Construction of Global Governance. London: Routledge. Pp. 99-124.

Blumenfeld, H., (1967), Theory of City Form: Past and Present, in P. Spreiregen (Ed), The Modern Metropolis: Selected Essays by Harold Blumenfeld. Cambridge, Mass.: MIT Press. Pp. 1837.

Braudel, F. , (1972); The Mediterranean; volume one, translated by S. Reynolds. London: Collins.

Brilmayer, L.; N. Klein, (2001), Land and Sea: Two Sovereignty Regimes in Search of a Common Denominator, in New York University Journal of Law and Politics, vol. 73 (3), pp. $703-$ 768. Brown, Steven D. and Peter Lunt, (2002), A Genealogy of the Social Identity Tradition: Deleuze and Guattari and Social Psychology, in British Journal of Social Psychology, vol 41, pp. $1-23$.

Cohen, M., (2003), Travelling Genres, in New Literary History, vol. 34 (3), pp. 481-499.

Colombos, C.J., (1967) International Law of the Sea, 6th ed., Longmans. 
Cowen, D., (2015) The Deadly Life of Logistics. London: Minnesota University Press.

Cresswell T (2010) Towards a politics of mobility, in Environment and Planning D: Society and Space, Vol. 28, pp 17-31.

Deleuze, G. and F. Guattari, (2008), A Thousand Plateus. London: Continuum.

Dillon, M., (1996), Politics of Security. London: Routledge.

Douvere, F.; C.N.. Ehler, (2009), New Perspectives on Sea Use Management: Initial Findings from European Experience with Marine Spatial Planning, Journal of Environmental Management, Vol.90, pp.77-88.

Douvere, F., (2008), The Importance of Marine Spatial Planning in Advancing Ecosystembased Sea Use Management, in Marine Policy, Vol. 32, pp. 762-71.

Douvere, F.; F. Maes; A. Vanhulle; J. Schrijvers, (2007), The Role of Marine Spatial Planning in Sea Use Management: The Belgian Case, in Marine Policy, Vol.31, pp 182-191.

Dupuis, A. and D.C. Thorns, (1998), Home, Home Ownership and the Search for Ontological Security, in Sociological Review, pp. 24-47.

Easterling, K., (2005), Enduring Innocence; Global Architecture and its Political Masquerades. Cambridge Mass.; The MIT Press.

European Commission (2013) EC Maritime Affairs and Fisheries ‘Blue Growth: Unlocking the Potential of Europe's Oceans, Seas and Coasts. EU Publications Office.

Ehler, C, Douvere, F., (2007), Visions for a Sea Change. report of the First International Workshop on marine Spatial Planning. Intergovernmental oceanographic commission and 
man and the biosphere programme. IOC Manual and Guides no. 48, Dossier no. 4. Paris:

UNESCO.

Elden, S., (2013), Secure the volume: Vertical geopolitics and the depth of power, in Political Geography, volume 34, pp. 35-51.

Elden, S., (2009), Being-with as Making Worlds: the 'Second Coming' of Peter Sloterdijk, in Environment and Planning D: Society and Space, vol.27, pp. 1-11.

Fletcher, P., (2009), Disciplining the Divine. Aldershot, Hampshire: Ashgate.

Giddens, A., (1991) Modernity and Self. New York. Polity Press.

Giddens, A., (1990), The Consequences of Modernity. Stanford, CA: Stanford University Press

Graham, S., (2010), Cities Under Siege: The New Military Urbanism. London: Verso. Hale, John R., (2014), Lords of the Sea. London: Gibson Square.

Hallwood, P., (2008), An Economic Analysis of Drawing Lines in the Sea, in Ocean and Coastal Management, Vol. 51, pp 405-409.

Hannesson, R., (2006), The Privatization of the Oceans. Cambridge, Mass.: MIT Press.

Hellström, M., (2007) Situating Knowledge in Archiscape: A Traveller's Guide, in Belderbos, and Verbeke, (eds), The Unthinkable Doctorate: Proceedings of the Colloquium 'The Unthinkable Doctorate' at Sint-Lucas Brussels from 14-16 April 2005, Hogeschool voor Wetenschap en Kunst. Pp. 421-430.

Hillier, J., (2007), Stretching Beyond the Horizon: a Multiplanar Theory of Spatial Planning and Governance. Aldershot, Hampshire: Ashgate Publications. 
HM Government (2014), East Inshore and East Offshore Marine Plans; Executive Summary. London: Department for Environment, Food and Rural Affairs.

HM Government (March 2011), UK Marine Policy Statement. London.

Joas, M.; D. Jahn; K. Kern, (eds), (2008), Governing a Common Sea. London: Earthscan.

Joyce, P., (2003), The Rule of Freedom: Liberalism and the Modern City. London: Verso.

Kirk, E. A., (1999), Maritime Zones and the Ecosystem Approach: A Mismatch?, in RECIEL, Vol.8 (1), pp. 67-72.

Klauser, F. R., (2010), Splintering Spheres of Security: Peter Sloterdijk and the Contemporary Fortress City, in Environment and Planning D: Society and Space, vol. 28, pp. 326-340.

Krueger, R. B.; M.H. Nordquist, (1978), The Evolution of the 200-mile Exclusive Economic Zone: State Practice in the Pacific Basin, in Virginia Journal of International Law, Vol 19, pp $321-400$.

Laing, R.D., (1990), The Divided Self. London: Penguin.

Laing, R.D., (1990a), Sanity, Madness and the Family; Families of Schizophrenics. London: Penguin

Lehman, J. C., (2013), Relating to the sea: enlivening the ocean as an actor in Eastern Sri Lanka, in Environment and Planning D: Society and Space, vol13, pp.485-501.

Lobo-Guerrero, L., (2012), Connectivity as the strategization of space-the case of the Port of Hamburg, in Distinktion: Scandinavian Journal of Social Theory, vol.13 (3), pp. 311-322

Maes, F., (2008), The International Legal Framework for Marine Spatial Planning, in Marine Policy, Vol. 32, pp. 797-810. 
Meiner, A., (2010), Integrated Maritime Policy for the European Union - Consolidating Coastal and Marine Information to Support Maritime Spatial Planning, in Journal of Coastal Conservation, Vol. 14, pp.1-11.

Mitzen, J., (2006), Ontological Security in World Politics in European Journal of International Relations, vol. 12 (3), pp. 341-370.

Monmonier, M., (2010), No Dig, No Fly, No Go: How Maps Restrict and Control. Chicago: University of Chicago Press.

Monmonier, M. (2008), Coast Lines. Chicago: Chicago University Press.

Nye, J. S., (1975), Ocean Rule Making from a World Politics Perspective, in Ocean Development and International Law Journal, Vol.3 (1), pp. 29-52.

Osborne, T., and N. Rose, (1999), Governing Cities: Notes on the Spatialisation of Virtue, in Environment and Planning D: Society and Space, vol. 17, pp. 737-760.

Osherenko, G., (2006), New Discourses on Ocean Governance: Understanding Property Rights and the Public Trust, in Journal of Environmental Law and Litigation, Vol. 21. Pp317-381.

Oxman, B. H., (2006), The Territorial Temptation: A Siren Song at Sea; The American Journal of International Law Centennial Essays Volume 100, Page 830

Peters, K., (2012), Manipulating material hydro-worlds: rethinking human and more-thanhuman relationality through offshore radio piracy, in Environment and Planning A, vol. 44. Pp. 1241-1254.

Rancière, J., (2007), On the Shores of Politics. London: Verso 
Ryan, B. J.; (2013) Zones and Routes: securing a western Indian Ocean, in Journal of the Indian Ocean Region, vol. 9(2), pp.173-188.

Schäfer, N.; V. Barale, (2011), Maritime Spatial Planning: Opportunities and Challenges in the Framework of the EU Integrated Maritime Policy, in Journal of Coastal Conservation, Vol. 15, pp.237-245.

Schmitt, C., (2006), The Nomos of the Earth in the International Law of the Jus Publicum Europaeum. New York: Telos. .

Sloterdijk, P., (2013a), In the Interior World of Capital: Towards a Philosophical Theory of Globalization. Cambridge: Polity.

Sloterdijk, P., (2013) You Must Change Your Life. Cambridge: Polity

Sloterdijk, P., (2012), The Time of the Crime of the Monstrous: On the Philsophical Justification of the Artificial (trans. W. Hoban), in S. Elden (editor), Sloterdijk Now. Cambridge: Polity. Pp. 165-181.

Sloterdijk, P., (2011), Bubbles: Spheres I. Los Angeles, Calif.: Semiotex[e].

Sloterdijk, P. (2009), Rules for the Human Zoo: a response to the 'Letter on Humanism', in Environment and Planning D: Society and Space, vol. 27., pp.12-28.

Smith, H., D.; F. Maes; T.A. Stojanovic; R. C. Ballinger, (2011), The Integration of Land and Marine Spatial Planning, in Journal of Coastal Conservation, Vol. m15, pp. 291-303.

Steele, B. J., (2005) Ontological Security and the Power of Self-Identity: British neutrality and the American Civil War Review of International Studies 31 (3) pp, 519-540 
Steinberg, P.E.., (2011), The Deepwater Horizon, the Mavi Marmara and the dynamic zonation of ocean space, in The Geographical Journal, vol.177 (1), pp. 12-16.

Steinberg, P. E., (2009), Sovereignty, Territory and the Mapping of Mobility: A View from the Outside, in Annals of the Association of American Geographers, vol.99 (3), pp.467-495.

Steinberg, P. E., (2001), The Social Construction of the Ocean. Cambridge: Cambridge University Press.

Steinberg, P.E., (1999a), Lines of Division, Lines of Connection: Stewardship in the World Ocean, in The Geographical Review, Vol. 89(2), PP. 254-264.

Steinberg, P. E., (1999b), Navigating to Multiple Horizons: Towards a Geography of OceanSpace, in Professional Geographer, Vol. 51 (3), pp. 366-375.

Steinberg, P.E.,, (1999c), The Maritime Mystique: Sustainable Development, Capital Mobility and Nostaligia in the World Ocean, in Environment and Planning D: Society and Space, Vol 17, pp. 366-375.

St. Martin, K.; M. Hall-Aber, (2008), The Missing Layer: Geo-technologies, Communities, and Implications for Marine Spatial Planning, in Marine Policy, Vol.32, pp. 779-786.

Strain, L.; A. Rajabifard; I. Williamson, (2006), Marine administration and spatial data infrastructure, in Marine Policy, vol.30(4), pp. 431-441.

Struett, M. J.; J.D Carlson; M.T. Nance (eds), (2013), Maritime Piracy and the Construction of Global Governance. London: Routledge.

Suárez del Vivero, J.L.; J.C. Rodríguez Mateos, (2012), The Spanish Approach to Marine Spatial Planning. Maritime Strategy Framework vs. EU Integrated Maritime Policy, in Marine Policy Vol. 36, pp. 18-27. 
Suárez del Vivero, J. L.; J.C.. Rodríguez Mateos; D. Florido del Corral, (2009), Geopolitical Factors of Maritime Policies and Marine Spatial Planning: State, Regions, and Geographical Planning Scope, in Marine Policy, Vol. 33, pp 624-634.

Sutrop, U., 'Umwelt; Word and concept, Two Hundred Years of Semantic change, in Semiotica. Volume 2001, Issue 134, Pages 447-462

Tewdwr-Jones, M.; N. Gallent; J. Morphet, (2010), An Anatomy of Spatial Planning: Coming to Terms with the Spatial Element in UK Planning, in European Planning Studies, Vol.18, pp. 239-258.

Ten Bos, R., (2009), Towards and Amphibious Anthropology: Water and Peter Sloterdijk, in Environment and Planning D: Society and Space, vol. 27, pp. 73-86.

Toonen, H.M. and Jam PM van Tatenhove, (2013), Marine Scaping: The Structuring of Marime Practices, in Ocean and Coastal Management, vol. 75, pp. 43-52.

Tuan, Y., (1977), Space and Place: The Perspective of Experience. Minneapolis: University of Minnesota Press.

Wakefield, J., (2010), Undermining the Integrated Maritime Policy, in Marine Pollution Bulletin, Vol. 60, pp. 323-333.

Williams, A. J., (2011), Reconceptualising Spaces of the Air: Performing the Multiple Spatialities of UK Military Airspaces, in Transactions of the Institute of British Geographers, vol. 36, pp. 253-267.

Young, O., (2010), Institutional Dynamics: Resilience, Vulnerability and Adaptation in Environmental and Resource Regimes, in Global Environmental Change, Vol.20, pp 378-385. 
Young, O., (1982), Regime Dynamics: The Rise and Fall of International Regimes, in International Organization, Vol. 36 (2), pp. 277-297. 